\title{
Funkcjonowanie zakładów przemysłu obuwniczego regionu slupskiego w zmieniających się warunkach gospodarowania
}

Pozycję podmiotów gospodarczych w określonych strukturach społecznych i ekonomicznych wyznaczają w zasadniczy sposób założenia społeczno-ustrojowe państwa, w ramach którego funkcjonuje dany podmiot. W Polsce nakazowo-rozdzielczy system gospodarowania do końca lat osiemdziesiątych powodował centralne planowanie, kierowanie i zarządzanie. Odpowiednie resorty koordynowały rozwój poszczególnych dziedzin życia społeczno-gospodarczego. Przedsiębiorstwa przemysłowe posiadały niemal całkowicie określone reguły funkcjonowania. Zachowań przestrzennych nie regulowaly, w tym przypadku, ani ekonomiczne analizy kosztów i korzyści, ani percepcja przestrzeni społeczno-ekonomicznej kraju (Parysek 1994). Jednocześnie brak mechanizmów rynkowych i otwarcia na gospodarkę światową spowodował zanik konkurencyjnych zachowań przedsiębiorstw oraz niedocenianie innowacji, nakładów na badanie i rozwój, a w konsekwencji lukę technologiczną oraz niską jakość, słabą dynamikę i małą efektywność produkcji przemysłowej (Stryjakiewicz 1999).

Struktura przemysłu polskiego nie zawsze sprzyjała rozwojowi produkcji nowoczesnej, wymagała zatem zmian, które doprowadziłyby do zwiększenia jej nowoczesności i efektywności. Moment taki nastąpił w 1989 r., w którym ukształtował się nowy układ sił politycznych. Stworzono przesłanki dla transformacji systemowej w Polsce, której najważniejszym kierunkiem dzialań była szeroko pojmowana restrukturyzacja. Objęła ona wszystkie gałęzie przemysłu polskiego, w tym także branżę skórzaną i obuwniczą.

\section{Przemysł skórzany i obuwniczy w Polsce}

$\mathrm{Na}$ przelomie lat osiemdziesiątych i dziewięćdziesiątych polski przemysł skórzany (w tym obuwniczy) przeżywał pewien kryzys. Jego struktury oparte były na dużych wielozakładowych przedsiębiorstwach, takich jak: „Alka” w Słupsku, „Chełmek” w Chełmku, „Kobra" w Bydgoszczy, „Podhale” w Nowym Targu, czy „Radoskór” w Radomiu. W większości były to kombinaty, skupiające zakłady pokrewne: garbarnie, zakłady produkujące obuwie, odzież i galanterię skórzaną, gumownie, zakłady opakowań i szwalnie. W ograniczonym zakresie występowaly między nimi wzajemne powiązania. Nie zawsze występowały również zjawiska specjalizacji i kooperacji, na których oparta była produkcja obuwia np. we Włoszech, Niemczech, Francji, czy w innych krajach. Taki stan rzeczy powodowal, że pomimo dosyć nowoczesnego parku maszynowego, wydajność pracy w tych zakładach była stosunkowo niska (Szpunar 1999). Poza tym wysokie zatrudnienie, przestarzałe metody wytwarza- 
nia, zarządzanie właściwe przedsiębiorstwom państwowym, uniemożliwiły szybkie przystosowanie się do nowych wolnorynkowych warunków gospodarowania.

Dodatkowo na pogarszającą się kondycję przemysłu skórzanego wpłynęły także kłopoty na rynku surowcowym. Po pierwsze drastycznie wzrósł eksport z Polski skór surowych (z 5,5 tys. ton w 1989 r. do 41,0 tys. ton w 1990 r.), co nastapiło po otwarciu polskiej gospodarki na rynki zachodnie ze względu na wysoką jakość i niską cenę tego surowca w Polsce. Po drugie wysokiemu poziomowi eksportu towarzyszył postępujący regres w rolnictwie. Hodowla bydła, trzody chlewnej i owiec stawała się coraz mniej opłacalna, w związku z czym stan pogłowia np. bydła byl w 1993 r. niższy o 24\% od stanu w 1990 r. (Rydz 1996). W konsekwencji prowadziło to do niedoboru surowca w garbarniach, a w późniejszym etapie wpłynęło na zmiany w przemyśle obuwniczym.

Do najbardziej niekorzystnych przejawów działalności przemysłu obuwniczego w Polsce na początku lat dziewięćdziesiątych, które powodowały znaczne obniżenie produkcji, zaliczyć można:

- brak skutecznych sposobów przekształceń struktury organizacyjnej zakładów obuwniczych w obliczu gwałtownego wprowadzenia mechanizmów rynkowych,

- stale zwiększający się (często nielegalny) import obuwia głównie z Azji,

- załamanie się eksportu obuwia na rynki wschodnie,

- trudności ze zbytem, wynikające z likwidacji dotychczasowych struktur dystrybucyjnych i braku skutecznego tworzenia nowych silnych jednostek handlowych,

- załamanie finansowe przedsiębiorstw, przejawiające się z jednej strony rosnącymi zobowiązaniami wobec Zakładu Ubezpieczeń Społecznych oraz systemu podatkowego, z drugiej zaś strony brakiem środków na zakup surowców, marketing, reklamę czy dystrybucję.

Sytuacja nieznacznie zaczęła się stabilizować po 1994 r. Powstawało wówczas wiele małych i średnich zakładów prywatnych, opartych na rozwijającym się rzemiośle, bądź wokół restrukturyzujących się przedsiębiorstw państwowych. Przykładem może tutaj być Radom, Słupsk czy też Nowy Targ, gdzie wiele powstałych prywatnych firm zatrudniało byłych pracowników „Radoskóru”, „Alki” czy „Podhala”. Efektem tych działań był powolny acz systematyczny wzrost produkcji obuwia i skór (tab. 1). Ponowne załamanie nastappiło w roku 1998 na skutek ograniczenia eksportu, głównie na rynki wschodnie.

Tabela 1. Produkcja obuwia w Polsce w latach 1989-1999

\begin{tabular}{|c|c|c|c|c|}
\hline \multirow{2}{*}{ Lata } & \multirow{2}{*}{$\begin{array}{c}\text { Obuwie } \\
\text { ogólem }\end{array}$} & \multicolumn{3}{|c|}{ w tym: } \\
\cline { 2 - 5 } & \multicolumn{5}{|c|}{ skórzane } & \multicolumn{2}{|c|}{ tekstylne i z tworzyw sztucznych } & gumowe i tekstylno-gumowe \\
\hline 1989 & 161,0 & 55,1 & \multicolumn{3}{|c|}{ w mln par } \\
\hline 1990 & 105,0 & 43,3 & 96,1 & 9,8 \\
\hline 1991 & 71,1 & 28,5 & 55,3 & 6,4 \\
\hline 1992 & 58,6 & 22,8 & 38,4 & 4,2 \\
\hline 1993 & 50,7 & 20,9 & 32,4 & 3,4 \\
\hline 1994 & 56,3 & 22,6 & 27,0 & 2,8 \\
\hline 1995 & 62,8 & 24,6 & 30,7 & 3,0 \\
\hline 1996 & 69,9 & 26,9 & 35,2 & 3,0 \\
\hline 1997 & 71,8 & 27,7 & 39,7 & 3,3 \\
\hline 1998 & 57,1 & 24,4 & 40,9 & 3,4 \\
\hline 1999 & 50,4 & 22,6 & 30,1 & 2,6 \\
\hline
\end{tabular}

Źródło: Roczniki statystyczne przemysłu 1994, 1995, 1999, 2000, GUS. Warszawa. 


\section{Struktura przestrzenna przemyslu obuwniczego $\mathrm{w}$ regionie slupskim}

W prezentowanym opracowaniu podjęto próbę określenia zachowań przemysłu obuwniczego regionu słupskiego $\mathrm{w}$ warunkach transformacji gospodarczej. W badaniach posłużono się materiałami statystycznymi dostępnymi w Urzędach Statystycznych oraz materiałami zebranymi w bezpośrednich badaniach terenowych $w$ zakładach produkujących obuwie przeprowadzone zostały pod kierunkiem E. Rydza'.

W regionie słupskim² do 1989 r. największe znaczenie dla przemysłu obuwniczego posiadał kombinat Północnych Zakładów Przemysłu Skórzanego „Alka”, który produkował obuwie w Słupsku oraz posiadał oddziały szycia cholewek w Lęborku i Darłowie. Oprócz „Alki" istniały jeszcze inne zakłady produkujące obuwie lub jego elementy, np.: Spółdzielnia Pracy Obuwia Domowego „Wspólna Praca” w Lęborku oraz kilka mniejszych zakładów, które jednak nie miały większego znaczenia w kształtowaniu rynku. W latach dziewięćdziesiątych zaznaczyły się pewne zamiany w strukturze przestrzennej przemysłu obuwniczego w regionie słupskim. Przede wszystkim nastąpił istotny wzrost liczby podmiotów produkujących obuwie z 9 zakładów w 1989 r. do 38 zakładów w 2000 r. (ryc. 1).

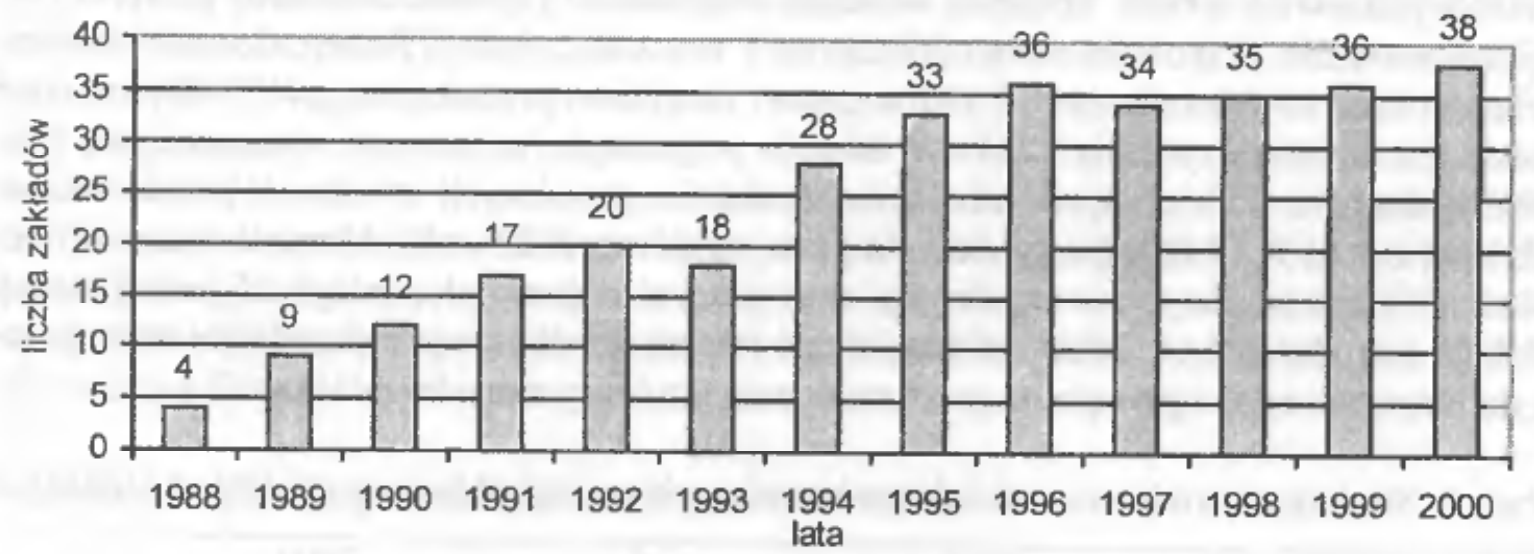

Ryc. 1. Liczba zakładów obuwniczych regionu słupskiego w latach 1988-2000

Jednocześnie nastąpiły zmiany w strukturze przestrzennej przemysłu obuwniczego. Większość zakładów obuwniczych funkcjonujących przed 1990 r. skupiona była na terenie miasta Słupska (blisko 75\%), np. „Alka”, „Mesir”, „Nord” czy „Tuzo”. W latach 1990-1995 wraz ze wzrostem liczby zakładów produkujących obuwie, zmieniły się też ich preferencje lokalizacyjne. Szereg nowych podmiotów lokowało swoje siedziby poza miastami, szczególnie w gminach podmiejskich. Zjawisko to w regionie słupskim najbardziej widoczne było w strefie podmiejskiej Słupska. Samo miasto w 1995 r. skupiało jeszcze $60 \%$ zakła-

\footnotetext{
${ }^{1}$ Badania terenowe przeprowadzono w ramach przygotowania pracy magisterskiej przez A. Świętosławską pod kierunkiem prof. E. Rydza w Instytucie Geografii Pomorskiej Akademii Pedagogicznej w Słupsku w 2001 r.

${ }^{2}$ Termin region słupski dotyczy obszaru byłego województwa słupskiego (istniejącego w latach 1975-1998), które od 01.01.1999 r. niemal w całości stało się częścią woj. Pomorskiego (z wyjątkiem gmin Postomino oraz Sławno, które weszły w skład woj. Zachodniopomorskiego). W statystyce polskiej wyróżnia się także pojęcie "podregion slupski” w odniesieniu do obszaru, który stanowi część woj. Pomorskiego.
}

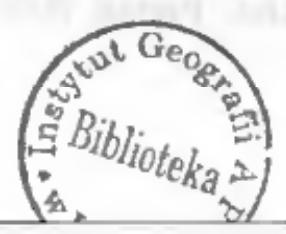


dów obuwniczych omawianego terenu, ale jednocześnie w podmiejskiej gminie Kobylnica zarejestrowanych było 6 tego typu zakładów ( $18 \%$ ogólnej liczby), wśród których największym pod względem zatrudnienia był „Man Fashion” z Losina (73 zatrudnionych). Przykładem może być tutaj ponadto przeniesienie produkcji obuwia firmy „Nord” ze Słupska do Strzelinka w gminie Słupsk.

Kolejne lata nie przyniosły znaczących zmian w strukturze przestrzennej przemystu obuwniczego $w$ regionie słupskim. Miasto Słupsk nadal pozostało miejscem produkcji obuwia największej liczby zakładów, a poza nim mieściły się one w gminach: Kobylnica, Ustka, Człuchów i mieście Lęborku.

\section{Struktura zatrudnienia w zakladach obuwniczych}

Oprócz zmian w strukturze przestrzennej przemysłu istotną sprawą dla restrukturyzujących się przedsiębiorstw, pozostaje kwestia zatrudnienia. Już w pierwszych latach przekształceń nastapiła wyraźna jego redukcja. Początkowo były to umiarkowane działania, gdyż większość zakładów przemysłowych przyjęła strategię „przechowywania” pracowników (Stryjakiewicz 1999). Podobną strategię działania w regionie słupskim przyjęło największe wówczas przedsiębiorstwo produkujące obuwie - „Alka”. Potwierdzeniem takiego stanu jest fakt, że w latach 1988-1990 w „Alce” spadkowi produkcji aż o 46\% towarzyszył spadek zatrudnienia tylko o $17 \%$. W efekcie pogorszyło to sytuację ekonomiczną tego przedsiębiorstwa, która doprowadziła następnie do grupowych zwolnień pracowników. $Z$ dawnej załogi w 1992 r. kontynuowało pracę zaledwie 1622 osób. Mimo to stanowili oni ponad $85 \%$ zatrudnionych w przemyśle obuwniczym regionu słupskiego. $\mathrm{Z}$ jednej strony redukcja zatrudnienia w „Alce”, z drugiej zaś tworzenie się nowych przedsiębiorstw przemysłu obuwniczego, wpłynęło na przekształcenia struktury zatrudnienia (tab. 2 ).

Tabela 2. Struktura zatrudnienia zakładów obuwniczych regionu słupskiego w 1993 r. i 2000 r.

\begin{tabular}{|c|r|r|r|r|r|r|r|r|}
\hline \multirow{2}{*}{$\begin{array}{c}\text { Zakłady } \\
\text { o liczbie } \\
\text { pracujących }\end{array}$} & \multicolumn{4}{|c|}{$1993^{*}$} & \multicolumn{4}{|c|}{2000} \\
\cline { 2 - 9 } & \multicolumn{2}{|c|}{ zaklady } & \multicolumn{2}{c|}{ zatrudnienie } & \multicolumn{2}{c|}{ zakłady } & \multicolumn{2}{c|}{ zatrudnienie } \\
\cline { 2 - 8 } & liczba & \multicolumn{1}{c|}{$\%$} & \multicolumn{1}{c|}{ osoby } & \multicolumn{1}{c|}{ \% liczba } & \multicolumn{1}{c|}{ Osoby } & \multicolumn{1}{c|}{$\%$} \\
\hline Ogólem & $\mathbf{2 1}$ & $\mathbf{1 0 0 , 0}$ & $\mathbf{2 9 7 4}$ & $\mathbf{1 0 0 , 0}$ & $\mathbf{3 8}$ & $\mathbf{1 0 0 , 0}$ & $\mathbf{2 4 4 1}$ & $\mathbf{1 0 0 , 0}$ \\
w tym: & & & & & & & & \\
$0-10$ & 6 & 28,6 & 20 & 0,8 & 15 & 39,5 & 67 & 2,6 \\
$11-20$ & 6 & 28,6 & $\mathbf{8 1}$ & 2,7 & 5 & 13,1 & 65 & 2,6 \\
$21-50$ & 4 & 19,0 & 160 & 5,4 & 7 & 18,4 & 248 & 10,5 \\
$51-100$ & 1 & 4.8 & 68 & 2,3 & 5 & 13,1 & 414 & 17,0 \\
$101-200$ & 1 & 4,8 & 105 & 3,5 & 2 & 5,3 & 262 & 10,6 \\
$201-500$ & 1 & 4,8 & 410 & 13,7 & 4 & 10.6 & 1385 & 56,7 \\
501 i więcej & 2 & 9,4 & 2130 & 71,6 & 0 & 0 & 0 & 0 \\
\hline
\end{tabular}

* dotyczy liczby zatrudnionych według działu obróbka skóry i produkcja wyrobów ze skóry Źródło: Przemysł województwa slupskiego, US, 1994; badanie terenowe prowadzone pod kierunkiem E. Rydza w 2000 r.

Liczba zatrudnionych w zakładach związanych z obróbką skóry i produkcją wyrobów ze skóry stanowiła w 1993 r. około $11,5 \%$ ogólnej liczby zatrudnionych w przemyśle w byłym województwie słupskim. Ponad $70 \%$ tej liczby przypadało na jednostki duże, 
które posiadały ponad 500 pracowników, natomiast na zakłady małe zatrudniające do 50 osób przypadało jedynie 8,9\%. Mimo coraz gorszej sytuacji nadal największym zakładem pozostawała „Alka”, w której w 1994 r. pracowało jeszcze 1097 osób. Stanowiło to 55\% zatrudnionych w przemyśle obuwniczym i 3,4\% w przemyśle ogółem w regionie słupskim.

Lata 1996-2000 charakteryzowały się na omawianym obszarze wyraźnym wzrostem liczby małych i średnich przedsiębiorstw prywatnych, co w efekcie zdecydowanie zmieniło strukturę zatrudnienia w tej branży przemysłu. W 1996 r. firmy sektora prywatnego zatrudniały już 1065 osób, co stanowiło 63,3 \% zatrudnionych w przemyśle obuwniczym. Zaznaczyć należy, iż po raz pierwszy sektor prywatny zatrudniał więcej osób niż sektor państwowy.

Aktualnie większość zakładów obuwniczych to jednostki małe zatrudniające do 50 osób, które stanowią ponad $70 \%$ wszystkich podmiotów gospodarczych tej branży, ale ich udział w zatrudnieniu wynosi około $15 \%$. Największy bowiem wpływ na kształtowanie rynku pracy w przemyśle obuwniczym wywierają zakłady duże zatrudniające powyżej 200 pracowników, tj. „Gino Rossi”, „Mesir”, „Alka” i „Nord” (454 pracowników), które koncentrują łącznie ponad 55\% zatrudnienia. Podkreślić należy, iż z krajobrazu regionu słupskiego znikły przedsiębiorstwa o liczbie pracowników powyżej 500 osób, co miało bezpośredni związek z redukcją zatrudnienia w Fabryce Obuwia „Alka” S.A. do poziomu 376 osób w 2000 r. Wszystkie te przemiany są następstwem dążenia do optymalizacji produkcji, polegającego na wyposażaniu zakładów w coraz nowocześniejsze maszyny i urządzenia do produkcji obuwia i w konsekwencji na zwiększeniu wielkości produkcji. Jednocześnie następuje redukcja zatrudnienia do poziomu opłacalności, co wynika nie tyle z niskiej wydajności pracy ludzkiej w stosunku do pracy maszyn, ile z relatywnie wysokich kosztów utrzymania pracownika, spowodowanymi wysokimi obciązeniami podatkowymi i opłatami ubezpieczeniowymi.

\section{Restrukturyzacja przedsiębiorstw państwowych}

Wraz ze zmianą orientacji produkcyjnej na orientację rynkową uległ zmianie wymiar przestrzenny zachowań przedsiębiorstw. Orientacja produkcyjna koncentrowała główną uwagę na tym wszystkim, co działo się w ich strukturach wewnętrznych. Orientacja rynkowa narzucila wyzwania otwarcia się na otoczenie, na rynek, na konsumenta, na jego potrzeby i na możliwości ich zaspokojenia (Parysek, Potrzebowski 1994). W regionie słupskim największe do końca lat osiemdziesiątych, produkujące obuwie przedsiębiorstwo „Alka" zostało objęte procesem restrukturyzacji naprawczej ${ }^{3}$.

Do 1989 r. PZPS „Alka” była dużym kombinatem przemysłu skórzanego ${ }^{4}$. W celu dostosowania się do nowych uwarunkowań gospodarczych nastąpił podział przedsiębiorstwa.

\footnotetext{
${ }^{3}$ Realizowana w przypadku, gdy nie zostały wprowadzone $w$ danym przedsiębiorstwie zmiany strukturalne, bądź wprowadzanie ich nastąpiło w niewłaściwym momencie, co w konsekwencji stawia przedsiębiorstwo przed zagrożeniem dalszego funkcjonowania (Nalepka 1998).

${ }^{4}$ Zarządzeniem Ministra Przemysłu Lekkiego z 22 grudnia 1972 r. powolano do życia Północne Zakłady Przemysłu Skórzanego „Alka”. W skład kombinatu obuwniczo-garbarsko-białoskórniczego weszły: Północne Zakłady Obuwia „Alka” w Słupsku z oddziałami w Darłowie i Lęborku, garbarnie w Kępicach, Dębnicy Kaszubskiej i Białogardzie oraz Fabryka Rękawiczek i Odzieży Skórzanej w Miastku z oddziałem w Złotowie.
} 
Już w 1989 r. została odłączona Fabryka Rękawiczek i Odzieży Skórzanej w Miastku (upadłość w 1996 r.). W latach 1990-1991 ze struktury przedsiębiorstwa wydzielono kolejne zakłady - garbarnie w Kępicach (upadłość w 1998 r.), Białogardzie i Dębnicy Kaszubskiej (likwidacja w 1998 r.).

Przekształcenia strukturalne nie zmniejszyły problemów ekonomicznych w PZPS „Alka”, które związane były przede wszystkim z likwidacją krajowej sieci dystrybucji, napływem obuwia zagranicznego, upadkiem państwowych garbarni i wstrzymaniem nieopłacalnego eksportu na rynki byłego Związku Radzieckiego. W takiej sytuacji następowało systematyczne obniżanie produkcji i zwolnienia pracowników. Znaczące ich ilości stanowiły zwolnienia na własne żądanie. Przyczyną ich było zahamowanie wzrostu płac, wstrzymanie premii, nagród dla pracowników, wprowadzenie odpłatności za dowozy do pracy. Narastające problemy doprowadziły do katastrofalnego zadłużenia fabryki. W $1991 \mathrm{r}$. rozpatrywano możliwość sprzedaży przedsiębiorstwa inwestorowi zagranicznemu. Przedłużające się jednak negocjacje z grupą kapitału amerykańskiego zniweczyły tę szansę.

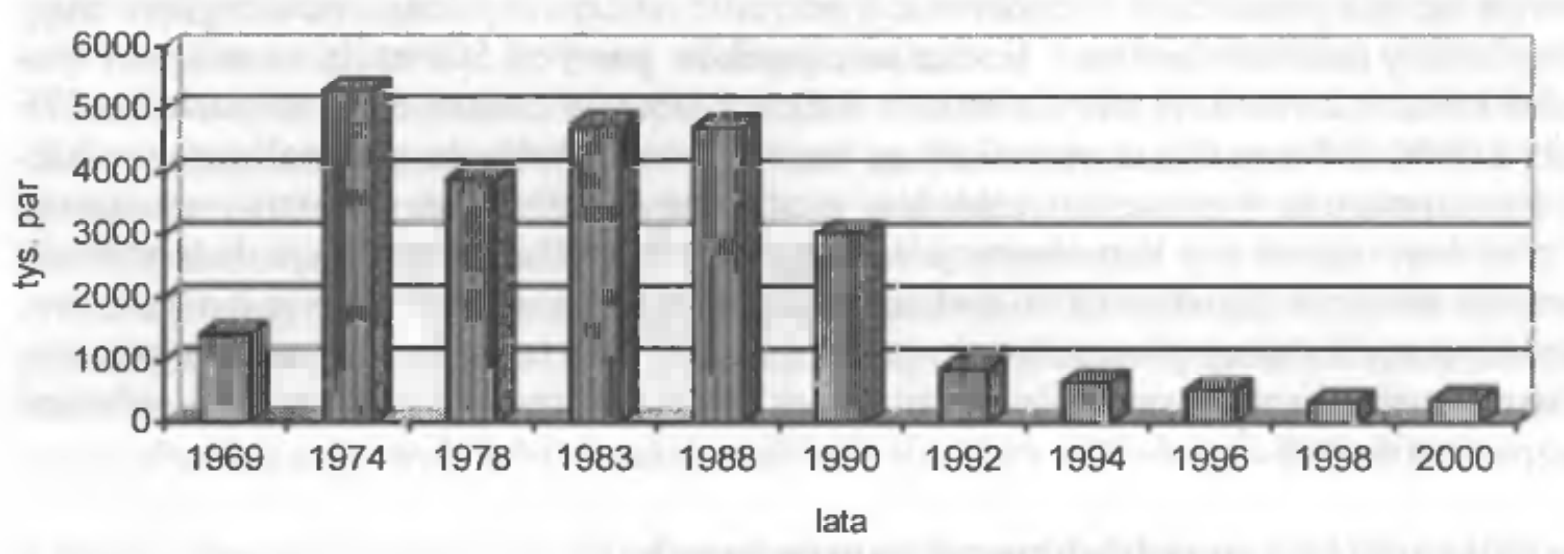

Ryc. 2. Produkcja obuwia w Fabryce Obuwia „Alka” w latach 1969-2000

W dalszej kolejności fabryka rozpoczęła negocjacje z bankiem, w wyniku których przejął on różne obiekty - magazyny, warsztaty naprawcze, bazę transportówą warsztaty samochodowe. W ramach programu zaspokajania wierzytelności banku i programu restrukturyzacyjnego kuratorium oświaty przejęło szkołę przyzakładową, natomiast mieszkania zakładowe zostały sprzedane osobom je zamieszkującym. Ze struktury przedsiębiorstwa wydzielono samodzielne podmioty gospodarcze, świadczące usługi na rzecz przedsiębiorstwa, tj. transportowe, remontowe, produkcji podeszew syntetycznych, szycia cholewek w oddziałach poza Słupskiem. Przekształcenia te nie przyniosły jednak oczekiwanych efektów i nastąpiło dalsze obniżenie produkcji obuwia (ryc. 2). Jedyną szansą stała się kolejna ugoda bankowa, wymogiem której było przekształcenie „Alki” w jednoosobową spółkę Skarbu Państwa i ograniczenie zatrudnienia do poziomu 1000 osób do końca 1994 r. W czerwcu 1994 r. inwestorem strategicznym nowopowstałej spółki Fabryka Obuwia „Alka" S.A. w Słupsku został Pomorski Bank Kredytowy oddział w Szczecinie (50,77\%). Pozostałe wierzytelności przejęły: Kępickie Zakłady Garbarskie „Kegar” w Kępicach (14,09\%), Bank Handlowy w Warszawie, Energetyka Cieplna Sp. z o.o. w Słupsku i Za- 
rząd Miasta Słupska. Wybieg ten spowodował jedynie krótkoterminową poprawę sytuacji firmy. Pomimo bowiem zastosowania wysokich nakładów na reklamę i promocję wyrobów, uczestnictwo w targach krajowych i międzynarodowych, szeroko rozumiane marketingowe działania związane z poszukiwaniem nowych rynków zbytu i odzyskiwaniem starych, nie osiągnięto zamierzonej rentowności. Ważną przyczyną niepowodzenia stała się niska elastyczność zarówno produkcji jak i adaptacji do nowych warunków. Wiązało się to tym samym z dalszym ograniczaniem zatrudnienia. Szczególnie niepokojący był fakt odchodzenia z fabryki wysoko wykwalifikowanych pracowników, głównie do konkurencyjnych tworzących się firm prywatnych, obiecujących dużo wyższe uposażenia.

Kolejną fazą przemian transformacyjnych w Fabryce Obuwia „Alka” był zakup jej akcji w 1997 r. przez łódzką firmę „But-S”. Najważniejszą modernizacją wprowadzoną do przedsiębiorstwa stała się zmiana systemu sprzedaży. W miejsce odbiorców - hurtowni przedstawicielskich, została stworzona zupełnie nowa sieć i struktury sprzedaży opierające się na bezpośredniej dystrybucji obuwia do sklepów. Kontynuowano ponadto promocję i reklamę, kładąc szczególny nacisk na jakość i modne wzornictwo produkowanego obuwia. Efektem innowacyjnego podejścia było przyznanie w 1999 r. „Alce” za serię półbutów męskich Godła Promocyjnego „Teraz Polska” i tym samym firma znalazła się w towarzystwie najlepszych polskich producentów.

\section{Zmiany struktury wlasnościowej}

W warunkach polskiej transformacji przedsiębiorstwa prywatne powstawały najczęściej poprzez prywatyzację istniejącej własności państwowej i spółdzielczej lub poprzez tworzenie nowych firm. W warunkach regionu słupskiego jedyne przedsiębiorstwo państwowe „Alka”, pomimo głębokiej restrukturyzacji, nie było w stanie sprostać wymogom rynku. Sytuację tę wykorzystały tworzące się firmy prywatne, które wypełniły powstałą na rynku obuwniczym lukę i swoją działalność rozpoczęły na bazie rozwiniętego państwowego przemysłu obuwniczego. Jako jedne z pierwszych zakładów obuwniczych powstały: „Man Fasion” w Losinie, „Mesir” w Słupsku oraz garbarnia w „Widzinie”. Założycielami i zarazem właścicielami nowych podmiotów byli dawni pracownicy „Alki”, którzy przewidzieli dezindustralizująca adaptację ${ }^{5}$ tego przedsiębiorstwa do zmieniających się warunków społeczno-gospodarczych. Tym samym stali się oni pionierami nowego wymiaru słupskiego przemysłu obuwniczego.

Od 1990 r. obserwuje się znaczny wzrost ilości prywatnych zakładów obuwniczych i zakładów bezpośrednio $\mathrm{z}$ nimi współpracujących. Na liście liczących się podmiotów produkujących obuwie znalazły się takie firmy jak: „Nord” w Strzelinku, „Perlak”, „Arco” i „Areks” w Słupsku, „Panavi” i „Elhan” w Lęborku. Firmy te pomimo słabego wsparcia instytucjonalnego elastyczniej reagowały na zmiany społeczno-gospodarcze okresu przejściowego. Powodowało to ich relatywnie szybki rozwój, pozwalający na przezwyciężenie recesji w przemyśle obuwniczym w początkowym okresie transformacji i zapoczątkowanie

\footnotetext{
${ }^{5}$ Pojęcia tego używa T. Stryjakiewicz (1999) i określa je jako formę adaptacji nieskutecznej, kończącej się znacznym spadkiem zatrudnienia i zmniejszeniem skali produkcji, konwerșą działalności w kierunku funkcji nieprzemysłowych (np. zamiana hali produkcyjnej na hurtownię, wynajem pomieszczeń na usługi), a w skrajnym przypadku - zamknięciem przedsiębiorstwa.
} 
umiarkowanego wzrostu od 1992 r. Od tego momentu sektor prywatny wkroczył w fazę samoregulacji rynkowej (Grzeganek-Więcek 1996). Znalazło to swój wyraz w ilościowych i jakościowych zmianach tego sektora. Na skutek wzrastającej konkurencji, mało profesjonalnych działań marketingowych i niewłaściwego niejednokrotnie zarządzania, niektóre z tych podmiotów nie utrzymały się na rynku (np. „Panavi” w Lęborku). Zakładów branży obuwniczej, które oparły się nowym wyzwaniom rynku pod koniec 1993 r. w regionie słupskim było około 20 . Większość z nich stanowiły jednostki małe, zatrudniające do 10 osób. Natomiast do największych należały: „Mesir”, „Gino Rossi” w Słupsku, „Man Fasion” z Łosina, i „Optima” ze Słupska produkująca podeszwy.

Przełomowym okresem dla regionu słupskiego okazał się rok 1994, kiedy to przybyło najwięcej firm związanych z produkcją obuwia, a udział sektora prywatnego w produkcji obuwia wzrósł do $47 \%$. Wymienić tutaj należy do dziś prężne zakłady takie jak: "Imez”, „Sab Jan” czy „Presko”. W tym czasie nastąpił też dynamiczny rozwój firmy „Nord”, której wielkość produkcji osiągnęła 270 tys. par rocznie, co stanowiło ponad $20 \%$ produkcji obuwia regionu słupskiego (ryc. 3). Fabryka obuwia „Nord” specjalizuje się w produkcji eleganckiego obuwia męskiego, tworząc wzornictwo wspólnie z projektantami włoskimi. Posiada ona nowoczesny i wydajny park maszynowy, przystosowany do produkcji obuwia najwyższej jakości, na poziomie europejskim. Wysoką jakość produkowanego obuwia potwierdzają znikome wielkości reklamacji, które nie przekraczają 0,3-0,8\% sprzedaży. Firma oparta jest w $100 \%$ na kapitale polskim, a jej założyciele i właściciele zarazem wywodzą się z byłych pracowników „Alki”. Prężna działalność tej fabryki uwidacznia się też w płynnym zbycie produktów, których $75 \%$ trafia na rynek krajowy.

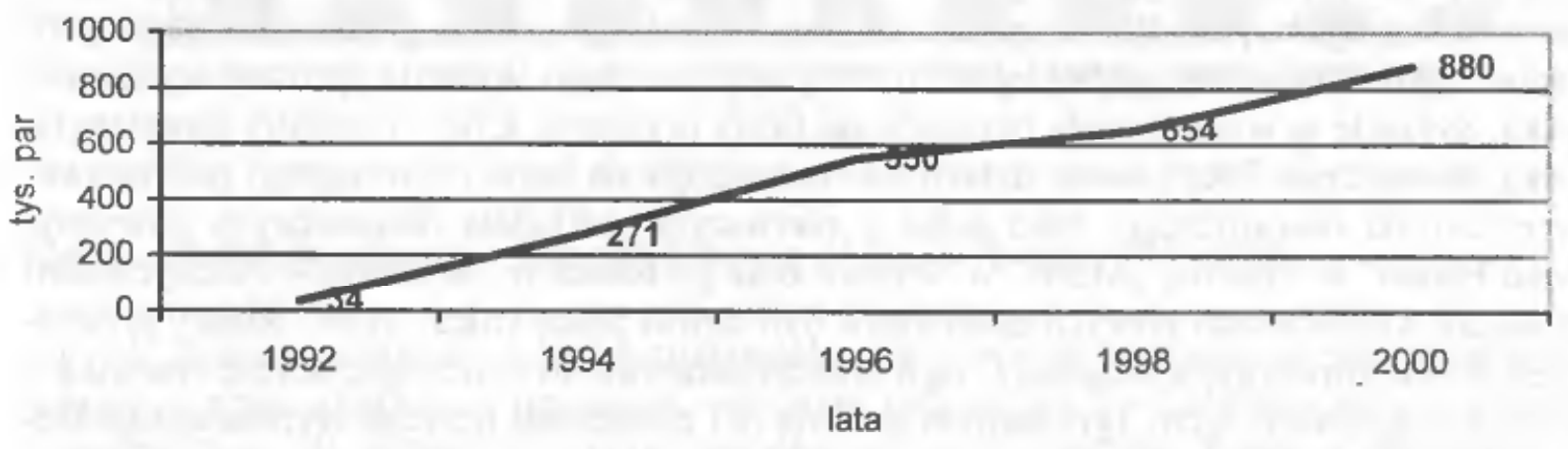

Ryc. 3. Produkcja obuwia zakładu obuwia „Nord” w latach 1994-2000

Kolejne lata charakteryzują się w regionie słupskim wyraźną stabilizacją rozwoju sektora prywatnego. Począwszy od 1995 r. ilość zakładów obuwniczych na omawianym terenie kształtowała się na poziomie około 35 podmiotów, a o poprawiającej się kondycji tych podmiotów świadczy chociażby fakt, systematycznie wzrastającego ich udziału w zatrudnieniu i produkcji przemysłu obuwniczego (ryc. 4). Wśród ankietowanych zakładów największym tempem wzrostu zatrudnienia okazał się „Man Fasion”, który w 1996 r. zatrudniał 5-krotnie więcej pracowników niż w roku 1994. Natomiast pod względem wielkości produkcji na pierwsze miejsce wysunęła się firma „Nord”, przewyższając nawet produkcję roczną „Alki”. Po raz pierwszy w historii słupskiego przemysłu obuwniczego pry- 
watna firma wyprodukowała więcej obuwia niż fabryka państwowa, będąca od czasów swojego powstania zdecydowanym liderem tej branży.

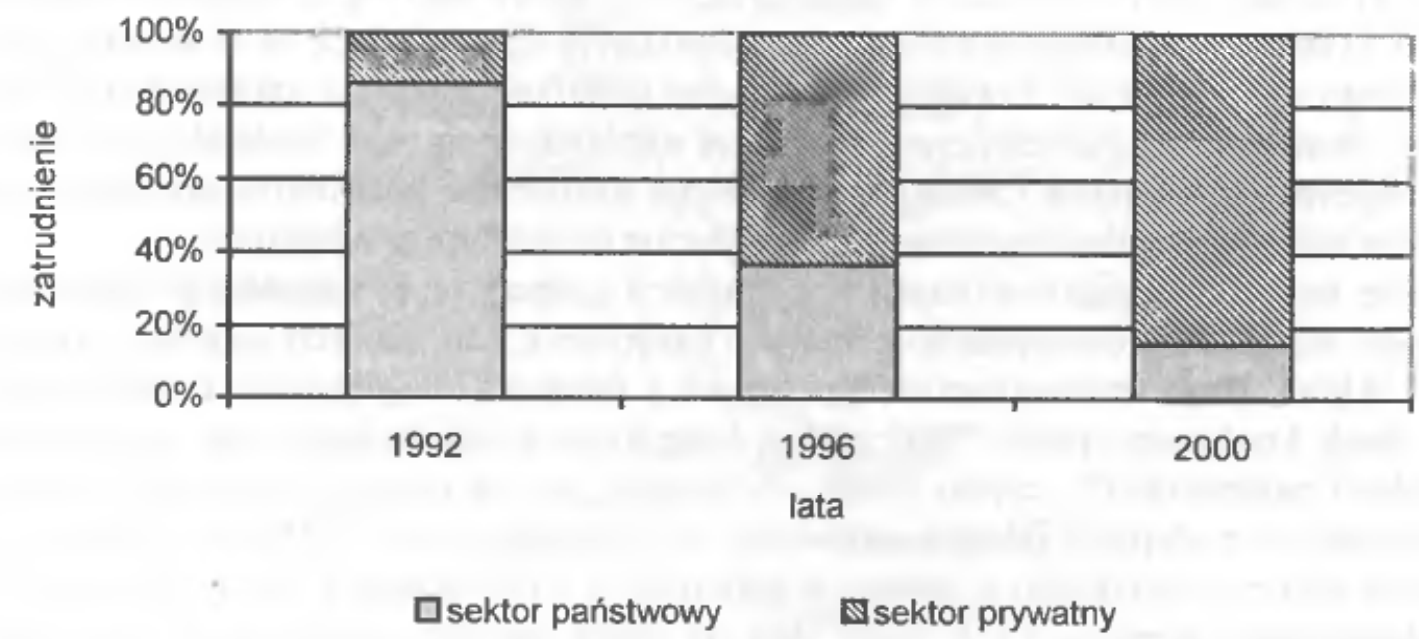

Ryc. 4. Struktura zatrudnienia w zakładach przemysłu obuwniczego regionu słupskiego według sektorów w 1992 r., 1996 r., i 2000 r.

Dzięki możliwościom szybkiego dostosowania się do nowych warunków gospodarczych firmy prywatne nie poddały się kolejnemu kryzysowi tej branży w 1998 r., który dotknął przedsiębiorstwa bezpośrednio handlujące z państwami Wspólnoty Niepodległych Państw. Najsilniejsze nadal pozostały na rynku i biorą czynny udział w kształtowaniu jego wizerunku.

Obecnie wiodącymi firmami sektora prywatnego produkującymi obuwie w regionie słupskim są: „Nord” ze Strzelinka, „Mesir”, „Perlak”, „Forma” i „Trio” ze Słupska, „Sab Jan”, „Presko” z Kobylnicy, „Man Fashion” z Łosina, „KMM” z Głobina. Cechą wspólną dotychczas wymienionych przedsiębiorstw prywatnych był $100 \%$ udział kapitału polskiego. W gospodarce polskiej funkcjonują natomiast podmioty $\mathbf{z}$ udziałem prywatnego kapitału zagranicznego. W regionie słupskim jedyną taką spółką prawa handlowego z udziałem kapitału zagranicznego (włoskiego) jest „Gino Rossi” ze Słupska. Z faktu tego nasuwa się wniosek, iż pomimo dość prężnego rozwoju słupskiego przemysłu obuwniczego w ostatnich latach, nie jest on jednak atrakcyjny pod względem inwestycyjnym dla kapitału zagranicznego.

\section{Powiązania pasywne i aktywne przedsiębiorstw}

Procesom produkcji, spożycia i wzrostu gospodarczego towarzyszą liczne akty wymiany między gospodarującymi podmiotami. Surowce, półfabrykaty i produkty finalne przeznaczone na zaopatrzenie produkcji i procesów wzrostu oraz na konsumpcję ludności stanowią przedmiot zbytu i zaopatrzenia oraz sprzedaży i kupna, zgodnie $\mathrm{z}$ aktualnym rozmieszczeniem podaży i popytu. Ruch dóbr materialnych stanowi nieodzowny warunek rozwiniętej gospodarki (Morawski 1968). Akty wymiany towarowej znajdują swe odbicie w przepływach towarowych, a każdy podmiot gospodarczy poprzez różnorodne związki z gospodarką kraju i świata rozwija swoje układy powiązań. L. Pakuła (1978) wyodrębnił 
dwa rodzaje powiązań przestrzennych: więzi pasywne w zakresie zaopatrzenia w surowce i więzi aktywne w zakresie zbytu produktów.

Realizowana od pierwszych lat dziewięćdziesiątych terapia szokowa przejścia do gospodarki rynkowej spowodowała, iż istotną rolę w rozwoju sektora prywatnego odegrały zmiany w systemie zaopatrzenia podmiotów gospodarczych polegające na zniesieniu administracyjnego rozdzielnictwa towarów. Zaniesiono wszelkie priorytety zaopatrzenia, reglamentację, obowiązkowe pośrednictwo w obrocie materiałowym oraz rozdzielnictwo dewiz na cele importu zaopatrzenia. Obecnie zaopatrzenie surowcowe podmiotów gospodarczych odbywa się więc na zasadach rynkowych, niezależnie od ich formy własności.

Nowe wyzwania rynkowe okresu transformacji gospodarczej $\mathrm{z}$ trudem przyjmowane były przez wielozakładowe przedsiębiorstwa państwowe, do których należała również słupska „Alka”. Brak mechanizmów rynkowych i otwarcia na gospodarkę spowodował u nich zanik konkurencyjności. Najczęściej zaopatrzenie ich opierało się na zakupach w zakładach państwowych, często filialnych. Jednak jak się okazało wcale nie tańszych i nie oferujących najlepszej jakości surowców. W przypadku „Alki” główne zaopatrzenie surowcowe (skóry) pochodziło z zakładów garbarskich z Białogardu i Kępic. Te dwie garbarnie dostarczały podstawowych ilości skór na rynek regionu słupskiego, w tym także producentom prywatnym. Do 1997 r. Garbarnia „Kegar” z Kępic była zatem największym dostawcą swoich wyrobów na rynek słupski. W najlepszych latach swojej działalności „Alka” pozostałe półfabrykaty (np. podeszwy) sprowadzała z całego kraju. Wykorzystywała też własną linię produkcyjną. Obecnie zakład korzysta $w$ dalszym ciągu z ofert producentów rodzimych oraz importuje pewne ilości surowców z Włoch.

Transformacja przyniosła znaczące przemiany w zakresie struktury rynku zaopatrzeniowego (ryc. 5). Powstawać zaczęły hurtownie sprzedające skóry znanych w Polsce garbarni oraz skóry importowane. Działalność swoją w subregionie słupskim rozpoczęły między innymi hurtownie: „Bimar” w 1997 r. - przedstawiciel garbarni „Brzeg” z Brzegu, „Asko” - przedstawiciel garbarni „Asko” w Nysie i przedstawiciel garbarni „Rugar” w Rumii.

Z przeprowadzonych badań wynika, że zakłady obuwnicze regionu słupskiego zaopatrują się w około 20 punktach związanych ze sprzedażą skór (hurtownie, producenci). Większość zakupionych skór (87\%) pochodzi z Polski, a zdecydowanie największą popularnością cieszą się wyroby garbarni „Asko” z Nysy, których używa do produkcji blisko $85 \%$ zakładów obuwniczych. W zakresie skór importowanych rozprowadzaniem tego surowca w regionie słupskim zajmują się hurtownie „Wim Soft” i „MB Market”. Część skór sprowadzana jest przez producentów obuwia bezpośrednio z zagranicy. Zazwyczaj jest to surowiec wyższej jakości, wykorzystywany głównie do produkcji eleganckiego obuwia wizytowego przez firmy: „Gino Rossi”, „Nord”, „Mesir”, „Alka”. Dominują tutaj skóry włoskie i w mniejszym stopniu hiszpańskie.

Oprócz skór ważne miejsce w strukturze zaopatrzenia odgrywają półfabrykaty i dodatki obuwnicze. Półfabrykaty typu podeszwy, podpodeszwy i zakładki najczęściej pochodzą z Gniezna, Borkowa, Tarnowa, Żar, Pułtuska, Zduńskiej Woli, Nowego Sącza, Częstochowy czy Myszkowa. Natomiast w liczne dodatki obuwnicze producenci zaopatrują się w Słupsku, Częstochowie i Krakowie (oczka), Łodzi (nici, ozdoby) i Wodzisławiu Śląskim (zamki). Produkty te są rozprowadzane głównie przez hurtownie zlokalizowane w Słupsku lub regionie słupskim, a będące często przedstawicielstwami krajowych lub zagranicznych producentów. 


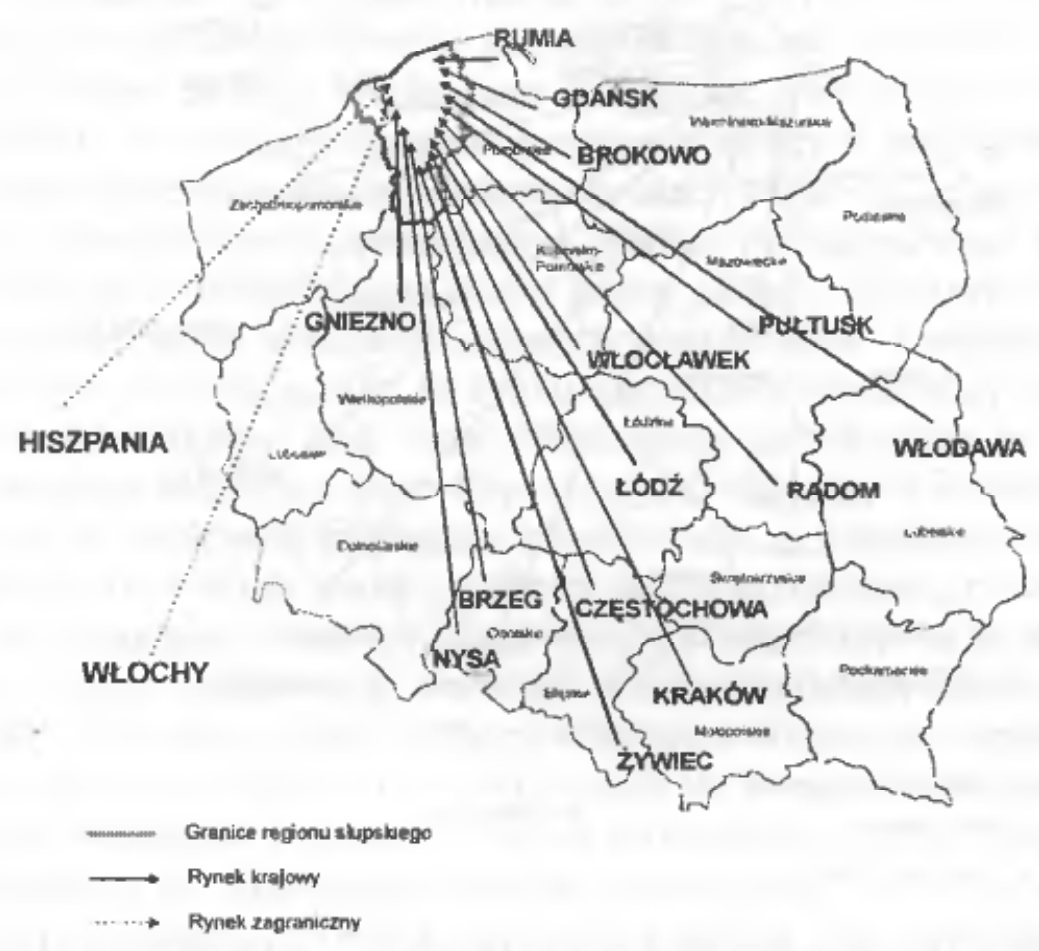

Ryc. 5. Powiązania zakładów obuwniczych regionu słupskiego w zakresie zaopatrzenia w $2000 \mathrm{r}$.

Uwzględniając kierunki zaopatrzenia słupskich producentów obuwia, należy zaznaczyć, że pochodzi ono z 11 województw, a szczególnie wysoki jest udział województwa Śląskiego, które dostarcza blisko 25\% zaopatrzenia oraz Małopolskiego (12\%), Mazowieckiego i Łódzkiego (po 9\%). Niemały jest także udział importu, który wynosi około $9 \%$.

Zaopatrzenie surowcowe regionu słupskiego wykazuje korzystne tendencje do zbliżania się licznych hurtowni i zakładów produkujących na potrzeby przemysłu obuwniczego do producentów obuwia. Wywołana w ten sposób większa konkurencja i zmniejszenie kosztów transportu powodują zmniejszenie kosztów produkcji i poprawę rentowności funkcjonowania słupskich przedsiębiorców.

Powiązania aktywne przemysłu obuwniczego regionu słupskiego ukierunkowane zostały w okresie transformacji przede wszystkim na działania marketingowe. Dotychczasowe bowiem działania eksportowe na wschód, głównie do byłego Związku Radzieckiego zostały wyraźnie ograniczone. Jedną z podstawowych przyczyn było załamanie się rynku rosyjskiego oraz trudna sytuacja gospodarczo-polityczna krajów postkomunistycznych. Obecnie zaznacza się tendencja do uzdrowienia tych kontaktów, lecz na zasadach rynkowych (ryc. 6). 


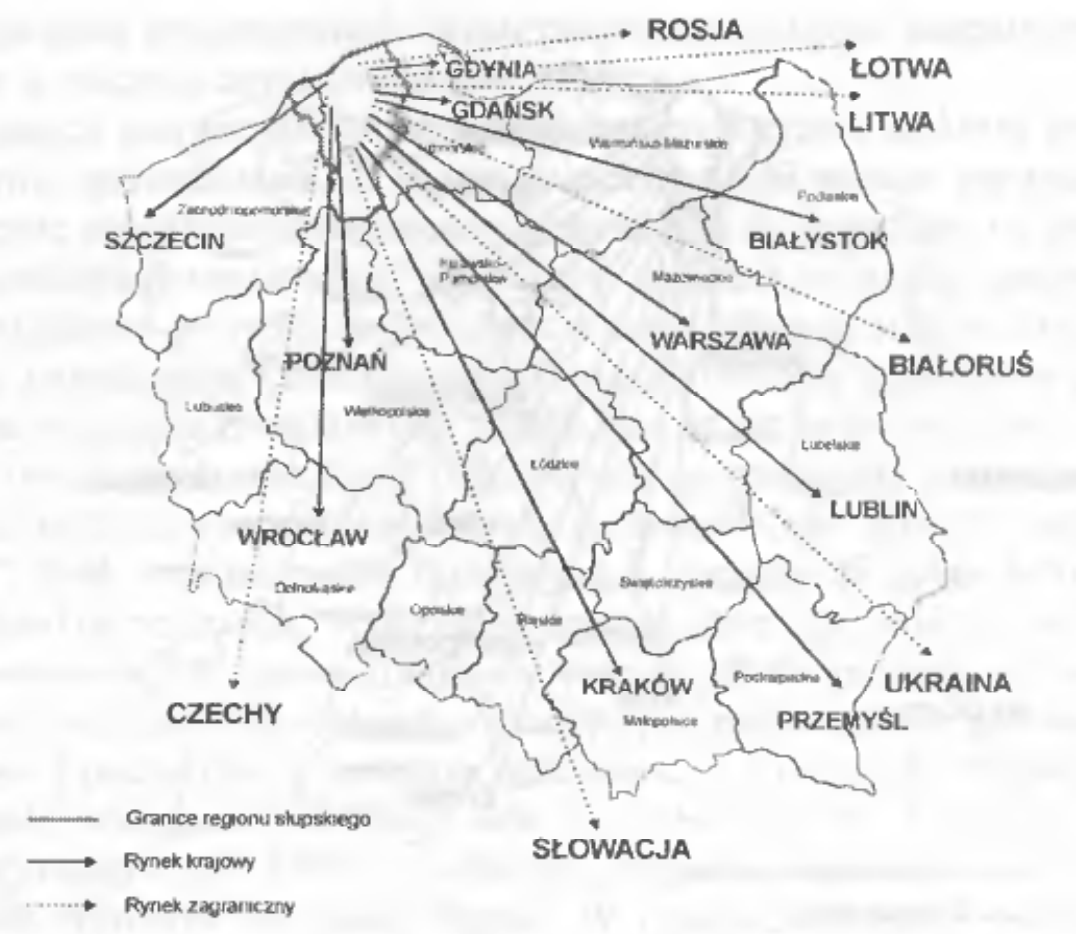

Ryc. 6. Powiązania zakładów obuwniczych regionu słupskiego w zakresie zbytu obuwia w 2000 r.

Z przeprowadzonych badań wynika, że aż 70\% całego eksportu kierowane jest na rynki wschodnie, głównie do Rosji - 22\%, na Ukrainę - 17\%, Lotwę - 13\%, Litwę - 9\% i Białoruś $-8 \%$. Około $1 / 4$ eksportu trafia natomiast na rynki czeskie i słowackie. Znaczny priorytet w eksporcie posiadają zakłady zatrudniające powyżej 100 osób. Sprzedają one poza granice kraju od $30 \%$ do $60 \%$ swoich wyrobów, natomiast mniejsi producenci (do 50 zatrudnionych) około $20 \%$ całkowitej produkcji.

Pożądaną sytuacją dla przedsiębiorstw obuwniczych byłaby długookresowa stabilność pod względem powiązań z odbiorcami. Na omawianym terenie jest to utrudnione między innymi ze względu na nasycenie i koncentrację zakładów, co wzmaga zachowania konkurencyjne między nimi. W sytuacji niestabilnego rynku zagranicznego słupskie przedsiębiorstwa zabiegają o odbiorców na rynku krajowym. Najwięcej wyprodukowanego na tym terenie obuwia trafia do sklepów w województwie Pomorskim (23\%) oraz do sąsiedniego województwa Zachodniopomorskiego (10\%).

Jednym z bardziej interesujących zachowań badanych przedsiębiorstw są powiązania ze wschodnimi województwami Polski. W większości odbiorcami są tam hurtownie obuwnicze, pośredniczące $w$ handlu $z$ państwami przygranicznymi. Dosyć silne powiązania występują takkże z rynkami województw: Mazowieckiego i Wielkopolskiego (po 8\%).

Do odbiorców indywidualnych wyroby słupskich producentów trafiają za pośrednictwem sklepów detalicznych. Latwiejszy dostęp do wybranych modeli obuwia (kolekcji) mają jednak mieszkańcy dużych miast, a przede wszystkim mieszkańcy regionu słupskiego.

Podsumowując należy podkreślić, iż przemysł obuwniczy regionu słupskiego pozostał nadal znaczącym ogniwem w systemie produkcji obuwia w kraju. Obecnie wytwarza on około $3 \mathrm{mln}$ par obuwia (głównie męskiego), co stanowi blisko $70 \%$ ogólnej produkcji 
obuwia w województwie pomorskim. Dzięki temu województwo pomorskie zajmuje 5 miejscu w kraju w produkcji obuwia, po województwach: lubuskim, łódzkim, śląskim i małopolskim. ${ }^{6}$ Silne tradycje obuwnictwa w regionie oraz istnienie wykwalifikowanej kadry zdecydowały, że pomimo trudności przystosowawczych przemysłu obuwniczego do nowych warunków gospodarowania, w ostatnich latach zaznacza się jego znaczący rozwój. Funkcjonujące przedsiębiorstwa produkujące obuwie na omawianym terenie zaznaczają doniosłą rolę szkoły skórzanej prowadzonej przez „Alkę”, która przyczyniła się do wykształcenia znacznej rzeszy wykwalifikowanych pracowników. Zamknięcie szkoły spowodowało, że zaczyna się uwidaczniać na rynku niedostatek właściwie przygotowanych pracowników. Słupskie zakłady, choć same dokształcają pracowników to jednak widzą potrzebę reaktywowania słupskiej szkoły obuwniczej lub utworzenia studium wzornictwa.

Przemiany w strukturze przemysłu obuwniczego potwierdzają także występującą w kraju tendencję rozwojową małej i średniej przedsiębiorczości, prawie całkowicie zlikwidowanej w gospodarce centralnie planowanej. Przedsiębiorstwa te są ważne dla lokalnej gospodarki, gdyż pozbawione wsparcia instytucjonalnego, elastyczniej reagują na wszelkie zmiany na rynku, a także szybciej adaptują innowacyjne metody rozwojowe. Są one również czynnikiem inicjującym wykształcenie się w regionie słupskim sieci powiązań - począwszy od producentów obuwia, poprzez producentów półfabrykatów, opakowań aż do firm zajmujących się dystrybucją obuwia. Coraz częściej do współpracy przystępują firmy reklamowe, plastycy, styliści, co znacznie poszerza sieci powiązań tego przemysłu $\mathrm{z}$ innymi branżami oraz $\mathrm{z}$ otoczeniem.

\section{Literatura}

Grzeganek-Więcek B., 1996, Rynkowe uwarunkowania rozwoju malych $i$ średnich przedsiębiorstw w procesie transformacji polskiej gospodarki. [w:] Małe i średnie przedsiębiorstwa jako stymulatory rozwoju gospodarczego. $Z$ badań w województwie opolskim, PAN, Katowice-Kraków, s. 20.

Morawski W., 1968, Przephywy towarowe i powiqzania międzyregionalne na obszarze Polski, KPZK PAN, Warszawa, s. 13.

Pakuła L., 1978, Problemy teoretyczno-badawcze form koncentracji przestrzennej przemystu. Folia Geografica, Series Geografica-Oeconomica, t. 11.

Parysek J. J., 1994, Zachowania przestrzenne przedsiębiorstw przemyslowych $w$ nowych warunkach spoleczno-ustrojowych, [w:] Funkcjonowanie przedsiębiorstw przemysłowych w zmieniających się warunkach gospodarowania, pod red. Z. Zioło, KrakówWarszawa, s. 22-30.

Parysek J. J., Potrzebowski G. A., 1994, Zachowania zakladów przemyslowych wytwarzajqcych artykuly rynkowe $i$ zaopatrzeniowe $w$ warunkach gospodarki rynkowej, [w:] $\mathrm{Za}-$ chowania przestrzenne przemysłu w zmieniających się warunkach gospodarowania, pod red. Z. Zioło, Kraków-Warszawa, s. 175-188.

Rajman J., 1962, Rozwój ośrodków przemyslowych nad Matq Panwiq, Katowice.

${ }^{6}$ Rocznik statystyczny przemysłu 2000, GUS, Warszawa. 
Rydz E., Jażewicz I., 1994, Przemiany struktur przestrzenno-galęziowych przemyshu województwa stupskiego $w$ zmieniających się warunkach gospodarowania. [w:] Zachowania przestrzenne przemysłu w zmieniających się warunkach gospodarowania, pod red. Z. Zioło, Wydawnictwo Naukowe WSP, Kraków-Warszawa.

Rydz. E., 1996, Kierunki rozwoju rolnictwa województwa słupskiego. [w:] 45-Zjazd Polskiego Towarzystwa Geograficznego-Polska w Europie Bałtyckiej, Wydawnictwo Uczelniane WSP w Słupsku, Słupsk, s. 179-208.

Stryjakiewicz T., 1999, Adaptacja przestrzenna przemystu $w$ Polsce $w$ warunkach transformacji, Wyd. UAM, Poznań.

Szpunar P., 1999, Przemyst obuwniczy w latach 1990-1997, [w:] Szkice i materiały do dziejów przemysłu skórzanego w Polsce, pod red. A. Lecha, Lódź, s. 230-232.

Troc M., 1996, Proces upadlościowy Nowotarskich Zakladów Przemyslu Skórzanego "Podhale" w Nowym Targu. [w:] Wpływ procesów transformacji gospodarki narodowej na funkcjonowanie jednostek gospodarczych i układów przestrzennych, pod red. Z. Zioło, Komisja Geografii Przemysłu PTG w Warszawie, Instytut Geografii WSP w Krakowie, Warszawa-Kraków, s. 129-137.

Zioło Z., 1996, Oddzialywanie procesów transformacji gospodarki narodowej na funkcjonowanie jednostek gospodarczych. [w:] Wpływ procesów transformacji gospodarki narodowej na funkcjonowanie jednostek gospodarczych i układów przestrzennych, pod red. Z. Zioło, Komisja Geografii Przemysłu PTG w Warszawie, Instytut Geografii WSP w Krakowie, Warszawa-Kraków, s. 146-151. 